\title{
The Effect of Freewriting on Developing Punctuation Marks in Paragraph Writings of Iranian EFL Intermediate Learners
}

\author{
Farzaneh Nouri \\ Department of English Language, Qaemshahr Branch, Islamic Azad University, Qaemshahr, Iran \\ Amir Marzban \\ Department of English Language, Qaemshahr Branch, Islamic Azad University, Qaemshahr, Iran
}

\begin{abstract}
Freewriting is writing whatever one knows or thinks for a certain length of time without stopping and editing till the time finishes. It's an easy and useful way of writing for generating ideas but it is sometimes full of errors. The current study examined a new area of freewriting which aimed to explore the effect of freewriting on development of learners' correct use of punctuation marks in their paragraph writings. The participants were 36 female intermediate students with Persian as their first language, enrolled in a six-week intensive English writing class. To homogenize the respondents they were given a version of Oxford Quick Placement Test (OPT) in order to assess the participants' proficiency level. As a pretest and posttest students were supposed to write about a topic which were scored according to a standard rubric. In order to test the inter-rater reliability of the scores given by the two raters, intra-class correlation coefficient was calculated. Mann Whitney test was used to compare the experimental and control group's OPT scores and Wilcoxon test was used to compare the pretest and posttest scores of each group separately and the results showed that the treatment affected the learners in experimental group significantly.
\end{abstract}

Index Terms - freewriting, punctuation marks, paragraph writing

\section{INTRODUCTION}

Writing in a second language seems to be the hardest skill to teach and to learn, because it needs learning many other skills (Ningrum et al., 2013). Writing gives the writer the opportunity to express his ideas, feelings, and viewpoints to others and convert them to visible manuscript. It is very important because it's used in many areas of lives and most of the students need to write some essays during their studies; also it's essential for expressing and preserving the ideas and memories. According to Robinson, "without writing there would be no history" (1995, p. 34). "Writing is used as a medium for collecting, preserving and transmitting information" (Graham, MacArthur, \& Fitzgerald, 2013, p. 5). However, writing encourages the writer to have physical and mental effort (Westwood, 2004) and the most important factor in writing is making students involved personally in learning process.

Punctuation marks also play an important role in giving our intended meaning to the reader. When they are used accurately, they guide the reader and make the comprehension of the text easier but when they are used wrongly or even wrong placement of them can change the total meaning of the sentence unintentionally and create ambiguity. According to Adekunle (1987), it's hard or sometimes impossible to write or understand a text without proper punctuation marks. So it is clear that not only at the intermediate level, but also at whatever level one must use correct pronunciation to write meaningfully and to be understood.

Freewriting according to Elbow and Belanoff (2000), is to write whatever comes into one's mind for a specified length of time without stopping, thinking, editing and evaluating. In Elbow's own words, "the only requirement is that you never stop." (1998, p. 3). When we freewrite, we express ourselves freely in what we write by our own voice. One of the most positive points of this kind of writing is that even quiet and shy students have something to write. By freewriting students become aware of their personal and emotional aspects which become evident in what they write. Findings suggest that students are more enthusiastic when they are involved in active learning that is "authentic, reflective and collaborative" (Scott, 2006, p. 6).

Some (e.g. Fox \& Suhor, 1986) believe that because freewriting is liberate and unstructured, it's incoherent and disorganized. Lots of studies have been done by many researchers on freewriting, however, this study differs from the previous ones. The current study aimed to explore the effect of freewriting in developing the students' correct use of punctuation marks in the area of paragraph writing. This study differs from the previous ones because the researcher focused on the correct use of punctuation when students freewrote which was not done before. So when students write paragraphs they will have less errors in term of punctuations. Also the students shared what they freewrote to the class which is called "public writing". When they share their freewritings to the class and when they listen to other classmates, they become familiar with different ways of thinking and writing. However, the unstructured nature of 
freewriting can be a challenge. The ultimate goal of this study was making students aware of the importance of freewriting as an interesting activity which can help them develop their punctuations which was neglected in freewritings before. The obtained results showed that freewriting could be an influential and effective learning tool to improve students' use of punctuations when they write paragraphs.

\section{LITERATURE REVIEW}

Writing is an important skill which enables the writer to communicate. "Writing is seen as a product constructed from the writer's command of grammatical and lexical knowledge, and writing development is considered to be the result of imitating and manipulating models provided by the teacher" (Hyland, 2008, p. 3). Writing with all its different purposes and forms, is a complex process because some researchers argue that writing is the sum of other language skills which entails the writer to master in listening, speaking, and reading (Chastain 1971; Finocchiaro 1958; Rivrse 1968).

Polio (2001) believes that when writer focuses on fluency the quality may decrease; however the quality is not important in freewriting. Jacobs (1986) believes that freewriting has three important aspects "concerning on content, not worrying about form, and writing without stopping" (p.282). Regarding this, free writing is a student-centered activity and increases the self-esteem and motivation of students (Jacobs, 1986). Freewriting can help both novice and experienced writers to reverberate their thoughts and their experiences and convert them into writing; reshaping their knowledge leads to decreasing the worries that many writers have while writing (Murray 2013; Murray and Moore 2006). According to Kamler, writing with ease and confidence requires letting go and even writing 'bull shit' (2001). To create knowledge is the main aim of freewriting, as suggested by Richardson (1998; 2000) and Kamler (2001). Writing for a specific length of time like for five or ten or twenty minutes but quickly and steadily and without stopping is the essential rule of freewritng (Elbow 2000; Goldberg 1986). Murray (2009) believes that new writers can particularly benefit from freewriting, because without being worried about being evaluated, they can articulate their own words and express their thoughts. In addition, Murray adds "You start to write, even if you are, in fact, unsure about where the writing is going" (2009, 93). Moreover, by freewriting, the writer can identify in which areas he is weak; why his ideas make sense or not. According to Richardson (1998; 2000), all human beings have two kinds of knowledge; tacit and intuitive. Elbow (2000) mentions that with the help of freewriting one can convert his implicit and tacit knowledge into explicit and written form of it and then go through it.

Badenhorst (2007, 2008), Elbow (2000), Goldberg (1986), and Murray (2009), believe that freewriting cannot be regarded as a result, but it is more like a procedure. According to Elbow (2000), by freewriting all the limitations existing in writing are eliminated. When the self-imposed restrictions for writing accurately and flawlessly are removed, freewriting keeps the writing alive and lets the writer exhibit his voice and attempts (Elbow 2000). That is to say as Elbow claims, writers "speak on paper" $(2000,86)$. Furthermore, when writers regularly do freewriting, they are more satisfied and pleased. Instead of elbow grease, writing is more like detecting and producing.

For Badenhorst (2007), Elbow (2000) and Goldberg (1986), after bringing the opinions and reflections together, freewriting lets them expand. It makes thinking better and it is a way to capture and extend what the writer wishes to say (Richardson 2000). Regarding freewriting, the researcher demonstrated what the advocates of freewriting such as Badenhorst (2008), Elbow (2000) and Goldberg (1986) believe in that freewriting has the capability of producing and gathering original opinions and beliefs. It is simple and fast while being very delightful and pleasant. Moreover, it removes the obstacles the writer faces and provides him with the confidence about himself and and his writing.

Murthy (2007) points out that punctuation plays very important role in developing writing skills. Therefore, the correct use of punctuation marks is very crucial in writing meaningfully. Manser (2006) also believes that the purpose of punctuation mark is making the meaning of the sentences clear; so correct use of punctuation marks is necessary to avoid writing meaninglessly. Pryse (1993) also asserts that a good piece of writing can be ruined by lack or inappropriate punctuation; therefore, if one wants to avoid misinterpretation, his writing should be correctly punctuated. Therefore, to be understood accurately, one must use correct punctuation marks.

\section{StATEMENT OF THE PROBLEM}

Freewriting is writing freely and continuously without concerning about the mechanics of writing, such as punctuation, spelling and grammar. Because in freewriting the quantity is important and it cannot be edited, so it's sometimes full of errors. But if teacher encourages the learners to focus on punctuations when they freewrite, they will make more accurate sentences in terms of punctuations in their future paragraph writings even without the direct help of teacher. Also learners of English as a foreign language suffer from lack of knowledge of punctuation marks and the correct use of them as tools for presenting their ideas in writings. Moreover, there is no research being done related to this issue which integrates punctuations with freewriting. The research question that guides this study is:

Does practicing freewriting help intermediate EFL learners improve their correct use of punctuation marks in paragraph writing?

Today it's essential to train competent and qualified learners in student-centered classes. This study can help bringing up autonomous writers who can articulate their own writings with more accurate punctuations than before. 


\section{METHOD}

\section{A. Participants}

The participants were 36 female intermediate students with Persian as their first language, enrolled in a six-week intensive English writing class in Shokuh-e- Iran Language Institute where the researcher was the instructor. Initially the participants were 50 and their level was supposed to be intermediate. To homogenize the respondents they were given a version of Oxford Quick Placement Test (OPT) and based on the results, 36 students were selected as the participants of the study.

\section{B. Materials and Instruments}

The first instrument was Oxford Quick Placement Test (OPT) was used to ensure the homogeneity of the participants in order to assess the participants' proficiency level. The second instrument was in the form of paragraph writing. The researcher selected Guided Paragraph Writing by TC Jupp \& John Milne (1972). In this book, different types of paragraph writings were presented and the researcher used it for both control and experimental groups. As a pretest and posttest, students were supposed to write a paragraph about a specified topic. The students' papers were scored according to a standard rubric which was Australian Curriculum, Assessment and Reporting Authority (ACARA) NAPLAN 2012, Persuasive Writing Marking Guide, that is presented in the appendix. The written paragraphs in pretest and posttest were graded by two raters and the two scores were then averaged. If the raters disagreed, that piece of writing was given to a third rater to grade its disputed aspect(s). The scores given by the third rater were then averaged with whichever of the two sets of scores that was closer to it. This suggestion was made by Paulus (1999) to guarantee the reliability of rating.

\section{Procedures}

First, the participants were homogenized based on their performance on the Oxford Quick Placement Test. Based on the results of the text, the intermediate learners were selected as participants of the study. Then they were randomly divided into two groups as control and experimental group. If there were students who were better in writing, they would be divided equally in both groups. The two groups received similar procedures in the class which were traditional approaches, but only the experimental group had an extra freewriting exercise each session focusing on punctuation marks. All paragraphs written in each session were discussed and corrected in the class; if time did not allow and all of them could not be corrected in the class, they were corrected at home by the teacher and main points were discussed on next session. During the term in each session students were provided with paragraph, paragraph writing, paragraph structures and other things related to paragraph writing in details which was introduced to them briefly during the first days. In each session some points of grammar were also illustrated briefly. Three days a week in six-week program students took part in the classes and the time of each session was ninety minutes. Encouraging students to consider the punctuation marks when they freewrite, is the final aim of the class to see the results if they use more accurate punctuation marks in their paragraph writings or not.

On the first day of instruction, for more explanations and better clarifications, paragraph and paragraph writing was explained to students; the way a paragraph is written and what a paragraph consists of. On the second day, different structures and characteristic of a paragraph was explained to students and some punctuation marks were explained to them in details. Then they were asked to write a paragraph on a specific topic with taught punctuations.

On the third day, the experimental group received complete explanations in details about the nature of freewriting, the way it should be done and also its benefits and the reason why they need to learn it for improving their English writing skills. Other punctuation marks were also explained in details. On the same day, the teacher gave a simple topic to students and asked them to freewrite for ten minutes and introduce themselves. For the next freewriting that they were supposed to write, students asked for additional time and another five minutes and they were given fifteen minutes to freewrite. The teacher explained to students that in freewriting whatever comes to their minds is what she wants and they should not worry for the mistakes they make. The teacher also clarified that students should not edit and no need to make a perfect piece of paper. By the time students finished their writing, the teacher asked them to read aloud what they wrote or exchange with another student. They did that and whenever time allowed, the teacher asked students to share their writings to more than one student for peer comments. In each session, before students started to freewite, the teacher wrote some necessary words on the board related to the topic they were going to write about.

On the fourth day, the teacher offered students a needs analysis survey regarding the class instructions and asked them about their favorite topics they want to write. In this way, freewriting was more enjoyable and pleasant for students to write about the topics they want. Each session the teacher tried to use the topics they suggested. Throughout the freewriting sessions over the six weeks, the teacher encouraged students to pay more attention to punctuations when they freewrote and feedbacks were given on correct or incorrect use of punctuation marks; also sometimes the class had a small conversation about the topic after the freewriting. The researcher noticed that when students freewrite and consider the punctuation marks, not only the quality of their freewritings because of their attention to punctuation marks did not decrease at all, but also what they freewrote was more accurate than before. The researcher decided to encourage students to have pair-work (after they freewote) because of two reasons. One is that students are not accustomed to group work yet. The other reason is that when a student works alone, shy and quiet students will remain 
silent, while talkative students always talk. When students read aloud, they become familiar with varieties of thoughts and opinions and this is valuable. Freewriting also equip students with self-confidence to make meaningful texts very quickly and easily. Writers could take turn to read aloud to the class what they freewrote with expressing their punctuation marks and ask others to give their opinions and even criticize the writer.

Students had the first test at the beginning of the six-week course, which involved writing a simple paragraph for twenty minutes on a specific topic. For the second test which was held at the end of the semester, they had a similar writing test with another topic to do in twenty minutes to assess their achievement in paragraph writing in term of punctuation marks at the end of the course. The pretest and posttest of the present study were rated by two raters with a standard rubric in order to compare the results at the beginning and at the end of the course. The standard rubric is presented in the appendix A.

\section{Data Analysis AND Results}

In order to estimate the reliability of the test and the extent to which the test results are generalizable to the population, the Cronbach's alpha was calculated to be 0.716 which reveals the acceptable reliability of the test. The results are shown as below:

TABLE 1.

THE RELIABILITY STATISTICS

\begin{tabular}{|l|l|}
\hline Cronbach's alpha & N \\
\hline 716 & 4 \\
\hline
\end{tabular}

Kolmogorov-Smirnov test was used to estimate the normality of the distribution of the data which is shown below:

TABLE 2:

KOLMOGOROV-SMIRNOV TEST RESULTS

\begin{tabular}{|l|l|l|l|l|l|l|}
\hline \multirow{2}{*}{} & \multicolumn{2}{|l|}{ Experimental } & \multicolumn{2}{l|}{ Control } & Opt & Control \\
\cline { 2 - 7 } & Pretest & Posttest & Pretest & Posttest & Experimental & .118 \\
\hline Statistic & .363 & .363 & .363 & .421 & .256 & $.200^{*}$ \\
\hline Sig. & .000 & .000 & .000 & .000 & .003 & \\
\hline
\end{tabular}

Table 3 shows the descriptive statistics for OPT, pretest and posttest scores. 18 participants' scores are included for the experimental group and 18 scores for the control group. Regarding the experimental group's pretest, the highest score equals 2 and the lowest one equals 1 . The mean is 1.55 and the standard deviation is .51. For the experimental group's posttest, the highest score equals 4 and the lowest one equals 3 . The mean is 3.55 and the standard deviation is .51. Regarding the control group's pretest, the highest score equals 2 and the lowest one equals 1 . The mean is 1.44 and the standard deviation is .51. Regarding the control group's posttest, the highest score equals 3 and the lowest one equals 2 . The mean is 2.66 and the standard deviation is .48.

TABLE 3:

DESCRIPTIVE STATISTICS FOR OPT \& PRE- \& POSTTEST AND OPT SCORES

\begin{tabular}{|l|l|l|l|l|l|l|}
\hline \multicolumn{2}{|c}{} & $\mathrm{N}$ & Minimum & Maximum & Mean & Std. Deviation \\
\hline \multirow{3}{*}{ Experimental } & Pretest & 18 & 1.00 & 2.00 & 1.5556 & .51131 \\
\cline { 2 - 7 } & Posttest & 18 & 3.00 & 4.00 & 3.5556 & .51131 \\
\hline \multirow{3}{*}{ Control } & Pretest & 18 & 1.00 & 2.00 & 1.4444 & .51131 \\
\cline { 2 - 7 } & Posttest & 18 & 2.00 & 3.00 & 2.6667 & .48507 \\
\hline \multirow{3}{*}{ Opt } & Experimental & 18 & 32.00 & 39.00 & 34.5000 & 2.20294 \\
\cline { 2 - 7 } & Control & 18 & 31.00 & 39.00 & 35.0000 & 2.22288 \\
\hline
\end{tabular}

According to table 4, Mann Whitney test is used to compare the experimental and control group's OPT scores. According to the results $\mathrm{U}=133.5, \mathrm{P}=0.358$ ), there is no significant difference between the two group's scores. The results of the comparison between respondents' pretest scores in both control and experimental group (U=144, $\mathrm{P}=0.511$ )show that there is no significant difference between them. But the experimental group who received the treatment, had better scores compare to control group and the results of the comparison between respondents' posttest scores in both control and experimental group $(\mathrm{U}=48, \mathrm{P}=0.000)$ show that there is significant difference between their scores.

TABLE 4:

RESULTS OF MANN-WHITNEY U TEST FOR OPT \& PRE- \& POSTTEST AND OPT SCORES

\begin{tabular}{|l|l|l|l|l|l|}
\hline & Mean Ranks experimental & Mean Ranks control & U & Z & Sig. \\
\hline Opt & 16.92 & 20.08 & 133.500 & -.919 & .358 \\
\hline Pretest & 19.50 & 17.50 & 144.000 & -.657 & .511 \\
\hline Posttest & 24.83 & 12.17 & 48.000 & -4.025 & .000 \\
\hline
\end{tabular}


Table 5 shows the results of the comparison between pretest and posttest scores of each group separately. Because the distribution of data was not normal, Wilcoxon test was used. There is a significant difference $(\mathrm{Z}=-3.861, \mathrm{P}=0.00)$ between experimental group's scores in pretest and posttest and according to the means (table 2) it is observed that the mean of posttest scores has increased 54\% compare to pretest scores and the treatment was effective. In control group also there is a significant difference $(\mathrm{Z}=-3.508, \mathrm{P}=0.000)$ between pretest and posttest exam and according to the means (table 2) it is observed that the mean of posttest scores has increased $45.8 \%$ compare to pretest score and in experimental group the mean of posttest scores compare to pretest score has increased $56.25 \%$.

TABLE 5:

RESULTS OF WILCOXON SIGNED RANKS TEST FOR EXPERIMENTAL AND CONTROL GROUPS

\begin{tabular}{|c|c|c|c|c|c|}
\hline & \multicolumn{3}{|c|}{ Posttest - Pretest } & \multirow[b]{2}{*}{ Z } & \multirow[b]{2}{*}{ sig } \\
\hline & Negative Ranks & Positive Ranks & Ties & & \\
\hline Experimental $^{*}$ & $0^{\mathrm{a}}$ & $18^{\mathrm{b}}$ & $0^{\mathrm{c}}$ & -3.861 & .000 \\
\hline Control $^{*}$ & $0^{\mathrm{a}}$ & $15^{\mathrm{b}}$ & $3^{\mathrm{c}}$ & -3.508 & .000 \\
\hline
\end{tabular}

$\begin{array}{ll}\text { a. } & \text { Posttest }<\text { Pretest } \\ \text { b. } & \text { Posttest }>\text { Pretest } \\ \text { c. } & \text { Posttest }=\text { Pretest }\end{array}$

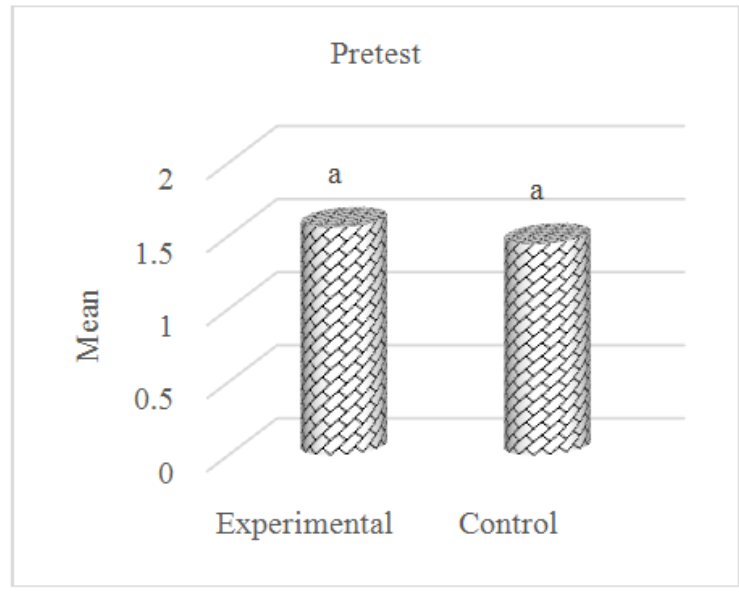

Fig. 1: The mean scores of pretest for control group and experimental group

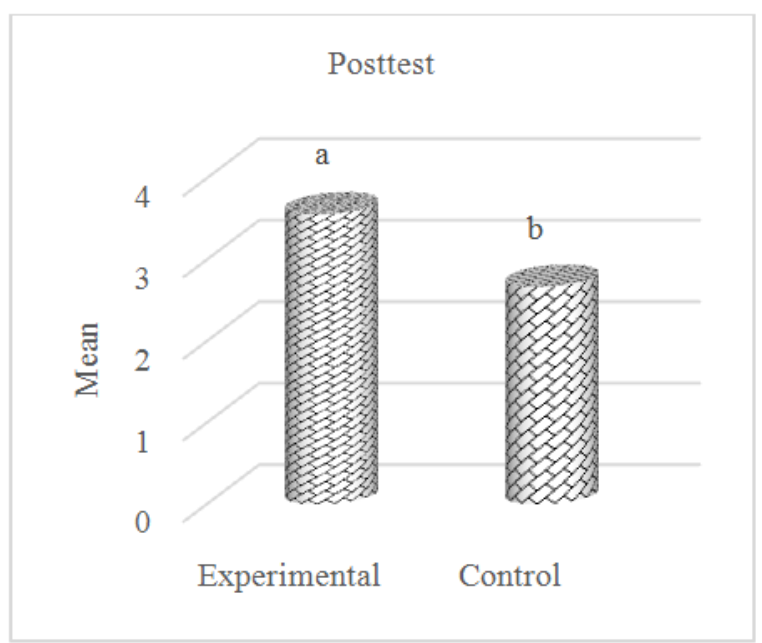

Fig. 2: The mean scores of posttest for control group and experimental group

Fig. 3 shows experimental group's performance on the pretest and posttest. It is obvious that the treatment affected the learners in this group significantly, as it is reflected in the mean scores in fig. 3. 


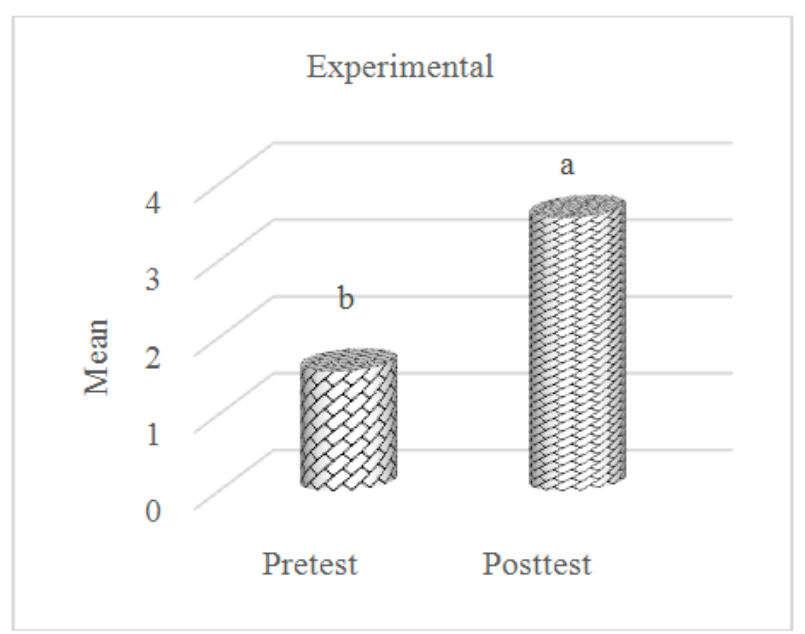

Fig. 3: experimental groups mean scores for pretest and posttest

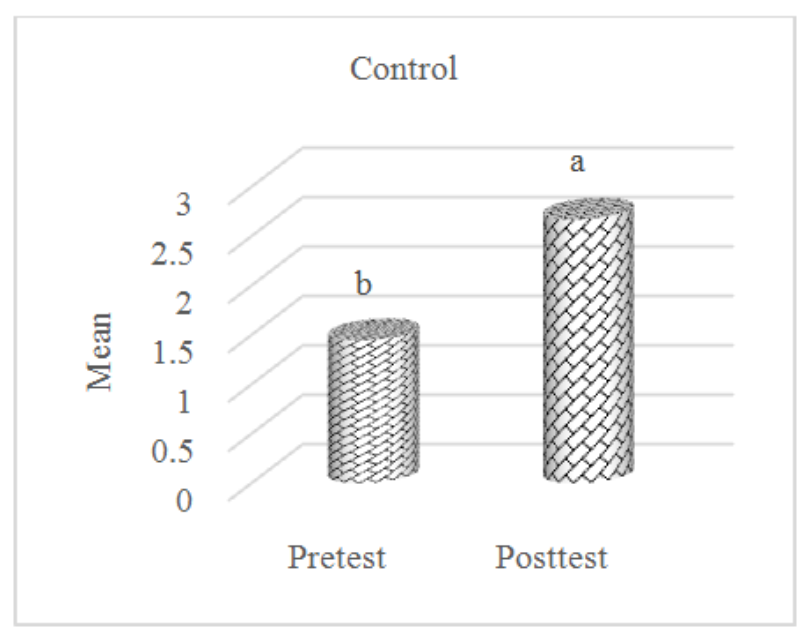

Fig. 4: control groups mean scores for pretest and posttest

In order to test the inter-rater reliability of the scores given by the two raters, Intra-class correlation coefficient was calculated. The results are shown below:

TABLE 6:

INTRA-CLASS CORRELATION COEFFICIENT

\begin{tabular}{|c|c|c|c|c|c|c|}
\hline & & \multirow{2}{*}{$\begin{array}{c}\text { Intra class } \\
\text { Correlation }\end{array}$} & \multicolumn{4}{|c|}{ F Test with True Value 0} \\
\hline & & & Value & df1 & df2 & Sig \\
\hline \multirow{2}{*}{ Pretest } & Experimental & .882 & 8.500 & 17 & 17 & .000 \\
\hline & Control & .730 & 3.706 & 17 & 17 & .005 \\
\hline \multirow{2}{*}{ Posttest } & Experimental & .845 & 6.434 & 17 & 17 & .000 \\
\hline & Control & .857 & 7.000 & 17 & 17 & .000 \\
\hline
\end{tabular}

According to the results $(\mathrm{F}=8.5, \mathrm{p}=.000)$, the correlation between the two sets of the scores given to the experimental group by the two raters on the pretest is significant since the observed $\mathrm{p}$-value is less than .05 .

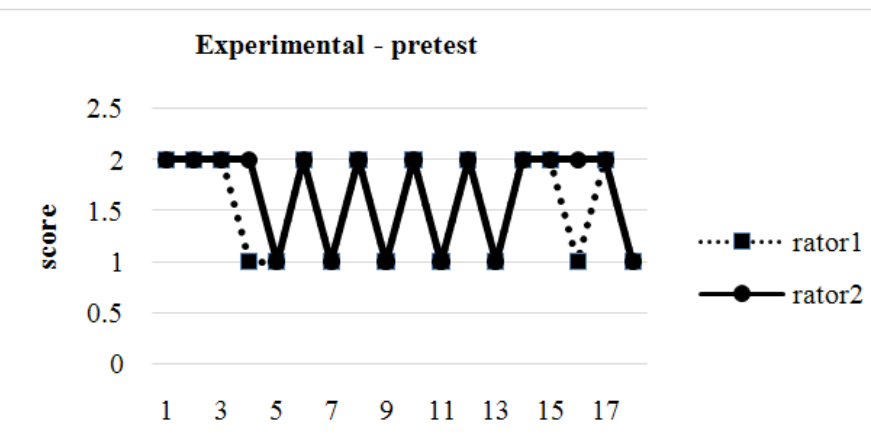

Fig. 5: Two raters' scores given to the experimental group on the pretest 
According to the results $(\mathrm{F}=3.706, \mathrm{p}=.000)$, the correlation between the two sets of the scores given to the control group by the two raters on the pretest is significant since the observed $p$ value is less than .05 . this is also visible in figure 6 below.

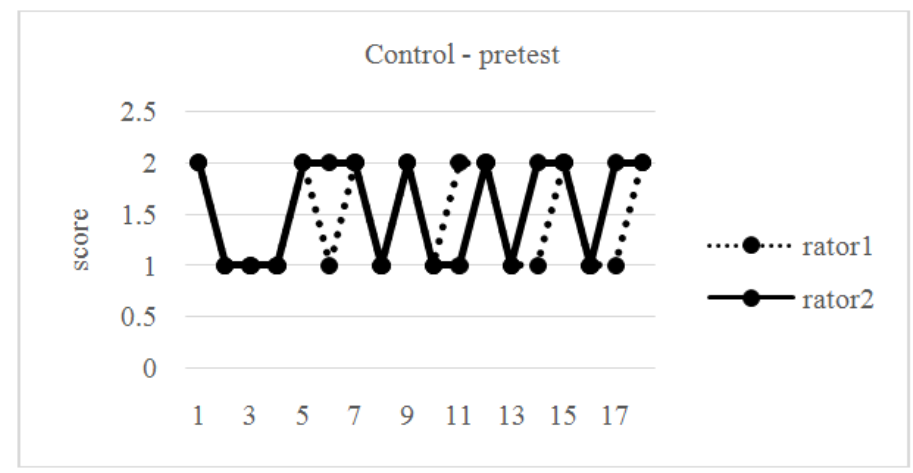

Fig. 6: Two raters' scores given to the control group on the pretest

According to the results $(\mathrm{F}=6.434, \mathrm{p}=.000)$, the correlation between the two sets of the scores given to the experimental group by the two raters on the posttest is significant since the observed $p$ value is less than .05 . this is also visible in figure 7 below.

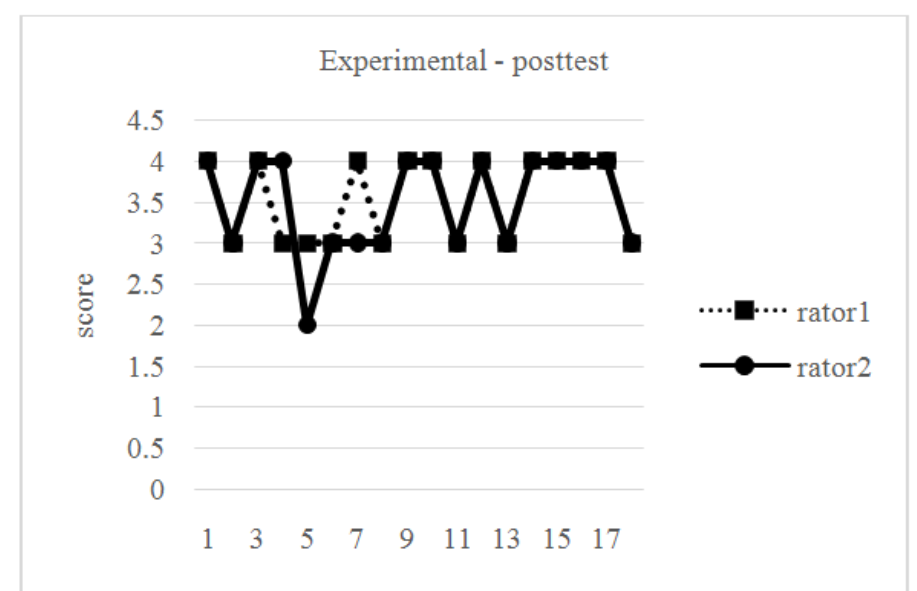

Fig. 7: Two raters' scores given to the experimental group on the posttest

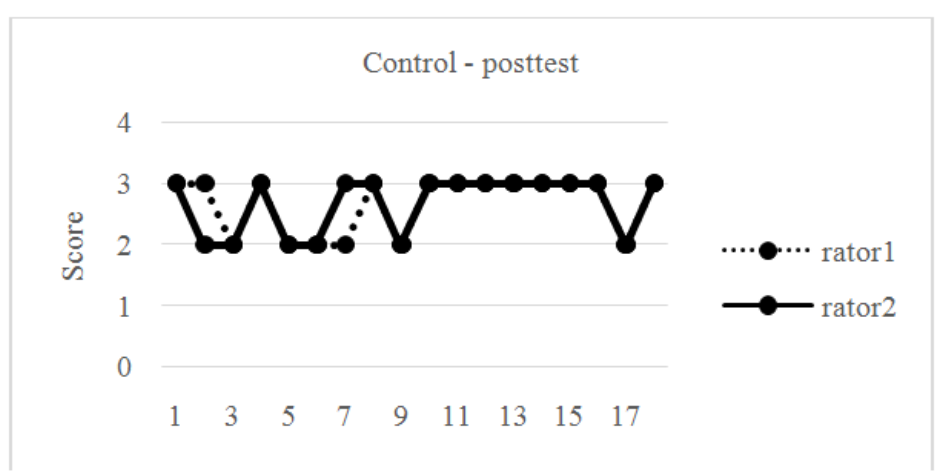

Fig. 8: Two raters' scores given to the control group on the posttest

\section{DISCUSSION AND CONCLUSION}

The present study aimed at investigating the effect of freewriting in developing the correct use of punctuations of Iranian EFL intermediate learners' written paragraphs. The results obtained from Wicoxon test revealed that freewriting has a positive influence on students' correct use of punctuation marks in their usual paragraph writings. Also the researcher noticed that the quality of their freewritings increased because of their attention to punctuation marks. When practicing freewriting with students which punctuations were emphasized, at the end of the semester the researcher noticed the students' enthusiasm in doing so and their increased confidence in producing sentences freely and autonomously with more accurate pronunciations from the beginning of the semester. When supervised freewriting becomes a usual and integral part of the teaching and learning process, learners will be more encouraged and 
empowered to think, to express their ideas with self-confidence and to have novel opinions to make discoveries through spontaneous writing while having correct pronunciation markers in their paragraph writings. Therefore, the findings of the study highlight the importance of freewriting on helping students make better and more accurate punctuations in sentences than what they were doing before.

The findings also suggest that this kind of freewriting can be applied in broader settings of teaching and learning. This study investigated only one level of proficiency, i.e. the intermediate level, and further studies are required to be conducted in other levels of proficiency and on other mechanics of writing to see if the same results will be accomplished. It is also advised to do the same research with different writing types such as diary, composition, essay and etc. More different factors which may establish important indicators of task performance can be considered in further studies such as: learners' motivation, their differences and their proficiency level. 


\section{Punctuation}

Skill focus: The use of correct and appropriate punctuation to aid reading of the text.

\begin{tabular}{|c|c|c|c|}
\hline & 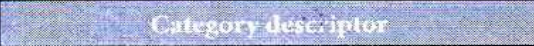 & & \\
\hline 0 & $\begin{array}{l}\text { no evidence of correct sentence } \\
\text { punctuation }\end{array}$ & \multirow{6}{*}{ 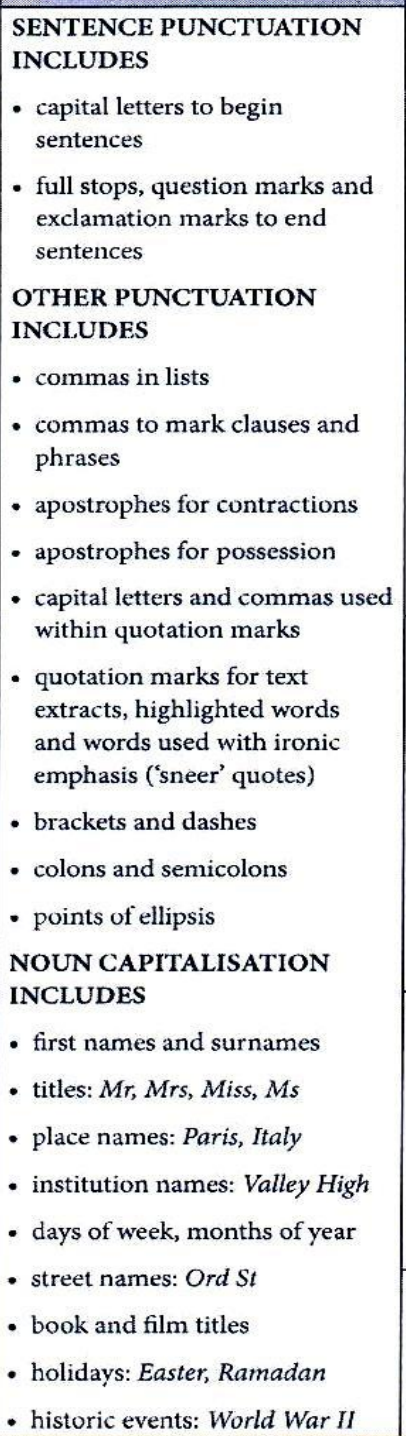 } & $\begin{array}{l}\text { PletRi DoLiSal (18) } \\
\text { it cruel to keep animals (24) }\end{array}$ \\
\hline 1 & $\begin{array}{l}\text { - correct use of capital letters to start } \\
\text { sentences OR full stops to end sentences (at } \\
\text { least one correct sentence marker) } \\
\text { punctuation is minimal and of little } \\
\text { assistance to the reader }\end{array}$ & & $\begin{array}{l}\text { Some animals cou'd die (20) } \\
\text { animals getting cewd (22) } \\
\text { animals will feel sad (28) }\end{array}$ \\
\hline 2 & $\begin{array}{l}\text { - some correct use of sentence level } \\
\text { punctuation (at least two accurately } \\
\text { punctuated sentences - beginning and end) } \\
\text { OR } \\
\text { - one correctly punctuated sentence AND } \\
\text { some other punctuation correct where } \\
\text { it is required (refer to list in additional } \\
\text { information) } \\
\text { provides some markers to assist reading }\end{array}$ & & $\begin{array}{l}\text { They won't face danger (32) } \\
\text { All animals started off (46) }\end{array}$ \\
\hline 3 & $\begin{array}{l}\text { - sentence level punctuation mostly correct } \\
\text { (minimum of } 80 \% \text { of five sentences } \\
\text { punctuated correctly) AND some other } \\
\text { correct punctuation (two or more different } \\
\text { examples of other punctuation) } \\
\text { OR } \\
\text { - accurate sentence punctuation with correct } \\
\text { noun capitalisation and no stray capitals, } \\
\text { nothing else used (four or more sentences) } \\
\text { provides adequate markers to assist reading }\end{array}$ & & $\begin{array}{l}\text { any other animal (30) } \\
\text { they try to break out (36) } \\
\text { I agree and don't agree (38) } \\
\text { My idea of a perfect zoo (42) } \\
\text { Cages and Zoos (50) } \\
\text { Under Certain } \\
\text { Circumstances (54) }\end{array}$ \\
\hline 4 & $\begin{array}{l}\text { - all sentence punctuation correct (no stray } \\
\text { capitals) } \\
\text { AND } \\
\text { - mostly correct use of other punctuation, } \\
\text { including noun capitalisation } \\
\text { provides accurate markers to enable smooth } \\
\text { and efficient reading }\end{array}$ & & $\begin{array}{l}\text { Some toys and games are } \\
\text { educational (40) } \\
\text { The lion's glorious hair (62) } \\
\text { If humans can have a voice } \\
\text { why can't animals. (66) } \\
\text { things should be regulated } \\
\text { (74) }\end{array}$ \\
\hline 5 & $\begin{array}{l}\text { - writing contains accurate use of all } \\
\text { applicable punctuation } \\
\text { provides precise markers to pace and control } \\
\text { reading of the text }\end{array}$ & & $\begin{array}{l}\text { zoos can have useful } \\
\text { purposes (70) } \\
\text { Food, water and other } \\
\text { nessasary supplies }(58)\end{array}$ \\
\hline
\end{tabular}

NOTES

- In first draft writing, allowances can be made for the very occasional omission of sentence punctuation at Categories 4 and 5 .

- 'Mostly' is approximately $80 \%$ but it is not intended that every use of punctuation is calculated rigorously.

- Do not penalise for different heading styles. The following styles are all considered acceptable:

- only the first letter capitalised (It is cruel to keep animals in cages or zoos)

- the first letter of all major words capitalised (It Is Cruel to Keep Animals in Cages or Zoos)

- all words capitalised (It Is Cruel To Keep Animals In Cages Or Zoos)

- all letters capitalised (IT IS CRUEL TO KEEP ANIMALS IN CAGES OR ZOOS)

- 'Splice' commas used to join two sentences are INCORRECT, e.g. The dog ate my home work, it was hungry. Do not score this as correct sentence punctuation or comma use.

\section{ACKNOWLEDGMENTS}

I wish to express my sincere appreciation to my friend, Dr. Siavash Zokaie who provided me with valuable comments and feedback. I also wish to thank the two raters and all the learners who participated in this study. 


\section{REFERENCES}

[1] Adekunle, M.A (1987). Functional English, Jos. Jos: University Press Ltd.

[2] Badenhorst, C. (2007). Research writing: Breaking the barriers. Pretoria: Van Schaik.

[3] Badenhorst, C. (2008). Dissertation writing: A research journey. Pretoria: Van Schaik.

[4] Chastain, K. (1971). Developing Second Language Skills Theory and Practice.US: Harcourt Brace Jovanovich.

[5] Elbow, P. (2000). Everyone can write. New York and Oxford: Oxford University Press.

[6] Elbow, P., \& Belanoff, P. (2000). A community of writers: A workshop course in writing (3rd).Boston:McGrawHill.

[7] Elbow, P. (1998). Writing without teachers. 2nd Edition. Oxford: Oxford University Press.

[8] Finocchiaro, M. (1958). Teaching English as a Second Language. New York: Harper

[9] Fox, D. \& Suhor, C. (1986). Limitations of free writing. English Journal, 75 (8), 34-36.

[10] Goldberg, N. (1986). Writing down the bones. Freeing the writer within. Boston and London: Shambhala.

[11] Graham, S., MacArthur, C. A., \& Fitzgerald, J. (2013). Best practices in writing instruction (2nd). NewYork, NY: Guilford.

[12] Hyland, K. (2003). Second language writing. New York, NY: Cambridge University Press.

[13] Jacobs, G (1986). Quick writing: a technique for invention in writing. ELT Journal, 40(4), 282-290.

[14] Kamler, B. (2001). Relocating the personal: A critical writing pedagogy. Norwood, SA: Australian Association for the Teaching of English.

[15] Manser, M.H. (2006). Guide to good writing, New York: An imprint of Infobase Publishing.

[16] Murray, R. (2009). Writing for academic journals. 2nd Edition. Maidenhead Bks and New York: Open University Press and McGraw Hill.

[17] Murray, R. (2013). Writing for academic journals. Maidenhead and New York: Open University Press.

[18] Murray, R. and S. Moore. (2006). The handbook of research writing: A fresh approach. New York: McGraw Hill and Open University Press.

[19] Murthy, J.D. (2007). Contemporary English grammar, Lagos: Book Master.

[20] Ningrum, V., Rita, F. \& Hastini. (2013). E-Journal of English Language Teaching Society (ELTS), 1 (1), 1-13.

[21] Polio, C. (2001). Research methodology in second language writing research: The case of textbased studies. In T. Silva \& P. K. Matsuda (Eds.). On second language writing (91-115). Mahwah, NJ: Lawrence Erlbaum Associates.

[22] Pryse, B.E (1983). English without tears, Glasgow: Williams Collins Sons and Co. Ltd

[23] Richardson, L. (1998). Writing: A method of inquiry. In Handbook of qualitative research, ed. N. K. Denzin and Y. S. Lincoln, 345-371. Thousand Oaks, CA: Sage.

[24] Richardson, L. (2000). New writing practices in qualitative research. Sociology of Sport Journal 17: 5-20.

[25] Robinson, Andrew (1995). The Story of Writing: Alphabets, Hieroglyphs and Pictograms, NY: Thames and Hudson, Ltd.

[26] Rivres, M. (1968). Teaching Foreign Language Skills., LTD, London: The University of Chicago Press.

[27] Scott, G. (2006). Accessing the student voice: Using CEQuery to identify what retains students and promotes engagement in productive learning in Australian higher education. A Project Funded by the Higher Education Innovation Program and the Collaboration and Structural Reform Fund, Department of Education, Science and Training. Commonwealth of Australia.

[28] Westwood, P. (2004). Learning and Learning Difficulties: A handbook for Teachers. Australian Council for Educational Research, LTD: ACER Press.

[29] Wilhoit, Stephen. (1993). Critical Thinking and the Thematic Writing Course. The Writing Instructor 12 (1993): $125-132$.

Farzaneh Nouri, was born in Mashhad, Iran. She got her BA in English Language Translation from Payam Nour University, Mashhad, Iran in 2006. She got her MA in TEFL from Saint Louis University, Baguio city, Philippines in 2013. She is currently a Ph.D. student in TEFL in Islamic Azad University, Qaemshahr branch, Iran. She is a part time teacher in Islamic Azad University of Kashmar branch since 2014. Her research interests are teacher education, and teaching English as a foreign language.

Amir Marzban, born in Iran, obtained his Ph.D. in Teaching English as a Foreign Language from Islamic Azad University, Sciences \& Research Branch, Tehran, Iran. He is an assistant professor of TESOL working at Islamic Azad University, Qaemshahr, Iran. He has published papers in national and international journals and also has presented in many international conferences. His research interests include conversation analysis, L2 reading and writing, CALL and teacher education. 